Review

\title{
Advances in Ceramic Supports for Polymer Electrolyte Fuel Cells
}

\section{Oran Lori and Lior Elbaz *}

Chemistry Department, Faculty of Exact Sciences, Bar-Ilan University, Ramat-Gan, 5290002, Israel;

E-Mail: oran.lori@mail.huji.ac.il

* Author to whom correspondence should be addressed; E-Mail: lior.elbaz@biu.ac.il;

Tel.: +972-3-7384252.

Academic Editor: Minhua Shao

Received: 29 June 2015 / Accepted: 6 August 2015 / Published: 17 August 2015

\begin{abstract}
Durability of catalyst supports is a technical barrier for both stationary and transportation applications of polymer-electrolyte-membrane fuel cells. New classes of non-carbon-based materials were developed in order to overcome the current limitations of the state-of-the-art carbon supports. Some of these materials are designed and tested to exceed the US DOE lifetime goals of 5000 or 40,000 hrs for transportation and stationary applications, respectively. In addition to their increased durability, the interactions between some new support materials and metal catalysts such as $\mathrm{Pt}$ result in increased catalyst activity. In this review, we will cover the latest studies conducted with ceramic supports based on carbides, oxides, nitrides, borides, and some composite materials.
\end{abstract}

Keywords: fuel cells; ceramic support; durability; corrosion resistance

\section{Introduction}

The need for advanced alternative energy technologies for transportation, backup-, and main-power applications is undisputable. Of the three available technologies, batteries, solar cells, and fuel cells (FCs), the latter is considered to be the most promising option for such applications due to its low footprint, high energy density, and low maintenance costs. In addition, fuel cells do not require a complex logistical effort and can be easily deployed in any terrain and weather (e.g., fuel cells as backup power for cellular antennas 
in remote locations). Hence, there is a growing use of fuel cells across industries (e.g., server farms, forklifts, buses, cellular antennas, and cars).

One of the significant hurdles in the mass deployment and commercialization of this technology is the lifetime of the fuel cell, which is mostly limited by the stability and durability of the catalyst support. Further understanding and improvement of this technology is expected to increase fuel cells' lifetime and reliability, and lower their cost.

Carbon is the most common and preferred catalyst support material for polymer electrolyte membrane fuel cells (PEMFCs) and alkaline fuel cells (AFCs). It possesses most of the primary required features: it is abundant, and it has a high surface area and good electrical conductivity. However, the use of carbon is problematic due to its low resistance to corrosion. The electrode integrity and durability is currently a technical barrier [1] in PEMFCs and AFCs, especially for applications that demand high power. This is mainly due to the loss of the fuel cell performance as a consequence of the use of carbon supports. More specifically, the degradation and corrosion of carbon-based electrodes lead to losses in the overall activity of FCs, and this is usually attributed to catalyst dissolution and agglomeration, as illustrated in Figure 1. The complete oxidation of carbon by water, which leads to its corrosion, is a four-electron process with the production of four protons, as follows:

$$
\begin{gathered}
\mathrm{C}(\mathrm{s})+2 \mathrm{H}_{2} \mathrm{O} \rightarrow \mathrm{CO}_{2}+4 \mathrm{H}^{+}+4 \mathrm{e}^{-} \\
E^{0}=0.207 \text { vs. NHE }
\end{gathered}
$$
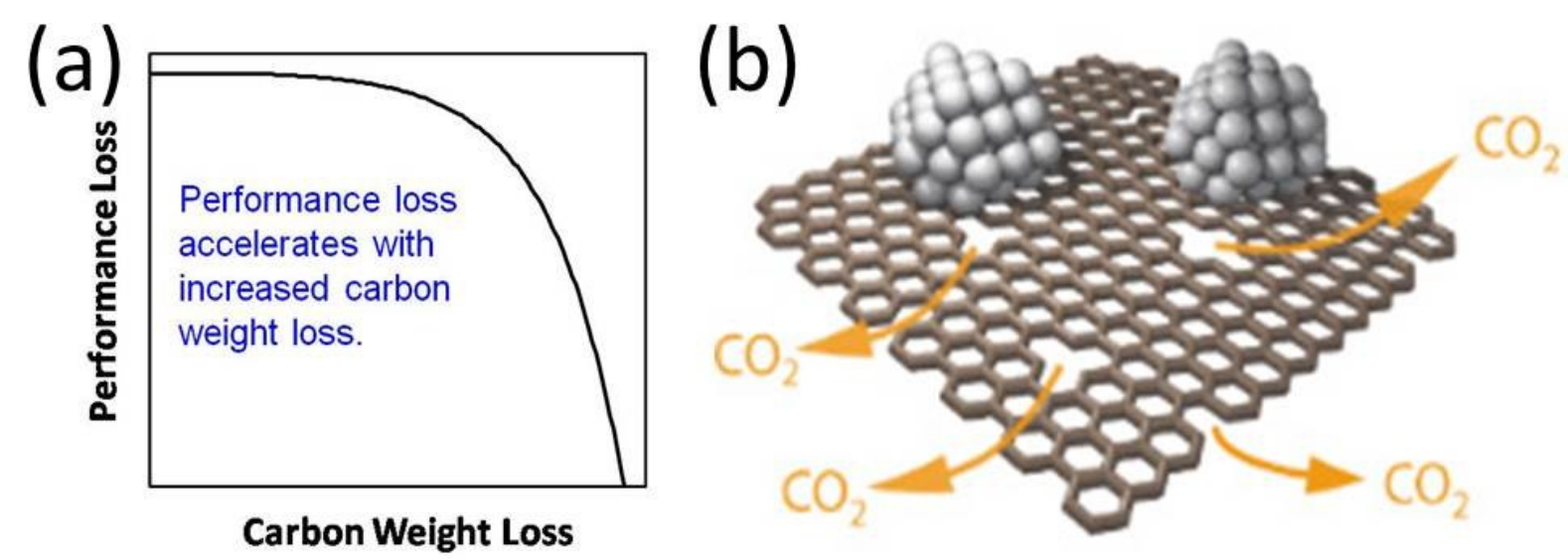

Figure 1. Relationship of carbon corrosion and activity loss in fuel cells (a) and illustration of catalyst detachment from corroded carbon (b) [2].

This is the potential of most power devices including batteries, solar cells, and fuel cells. When the $\mathrm{pH}$ increases, such as in AFCs, the proton activity is lowered. Consequently, the equilibrium shifts to the right in the above reaction and the rate of the carbon corrosion increases. The standard potential for complete oxidation was previously calculated by Pourbaix [3] as follows:

$$
E^{0}(\mathrm{~V})=0.207-0.0591 \times \mathrm{pH}+0.0148 \log \mathrm{P}_{\mathrm{CO} 2}
$$

The conditions in PEMFCs and AFCs are oxidizing, especially at the cathode [4-6]. As discussed above, these conditions are detrimental to the carbon electrodes and can significantly shorten the lifetime of the fuel cell $[7,8]$. 
Gruver et al. [7] showed that as the carbon support corrodes and turns into $\mathrm{CO}$ and $\mathrm{CO}_{2}$, the catalyst will either wash out or migrate and aggregate. Figure 2 presents images of a pre- and post-mortem sample from a fuel cell, where the loss of carbon (bright material) was observed and the platinum nanoparticles (dark material) have agglomerated (a significant increased in size was observed when compared to the particles in the Figure 2a). The result of both wash-out or aggregation of the catalyst is manifested in a decrease in the catalyst ECSA (Electro-Chemical Surface Area) in the case of precious group metal catalysts (PGMCs), or leaching and dissolution in the case of non-precious group metal catalysts (NPGMCs). One way to improve the stability of electrodes from corrosion in FCs is by the use of graphitic, nano-structured carbon materials, such as graphene nano-sheets, carbon nanotubes, and carbon nanofibers as catalyst supports [9-12]. The high degree of graphitized structures of these compounds provides a higher resistance to chemical and electrochemical oxidation. Another way is to use ceramic materials as catalyst supports [8].

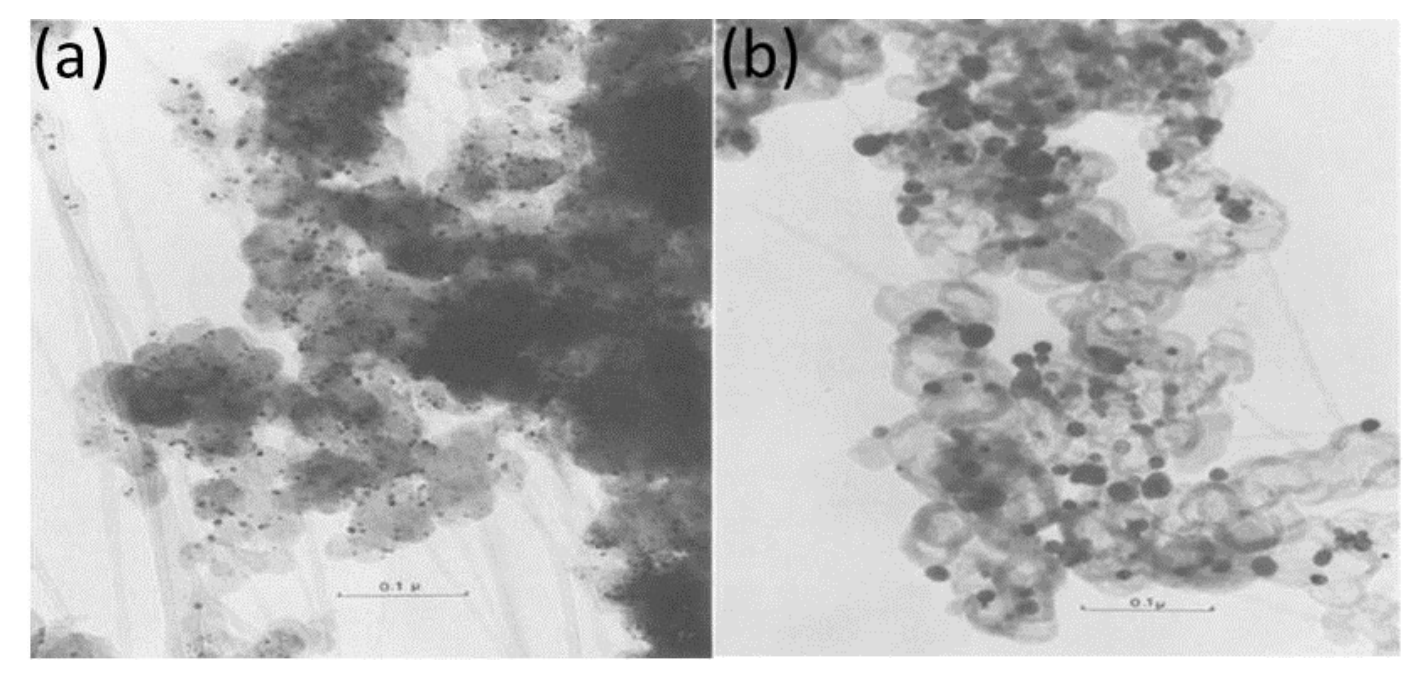

Figure 2. PEM fuel cell catalyst layer with support before (a) and after (b) use. Darker dots are Pt nanoparticles and the brighter material is carbon. [7] (Adapted from this reference with the permission of the Journal of Electrochemical Society).

Many ceramic supports were developed in order to increase the durability of fuel cells. Supports such as titanium-oxides [13,14], molybdenum-nitride [15], tungsten-oxide [16], and others were synthesized. Most of these possess some of the qualities needed for a good FC electrode (mechanical properties, thermal stability, chemical corrosion resistance), but lack others, such as good electrical conductivity and high surface area.

In this manuscript, we will review the recent advances in ceramic supports for polymer electrolyte fuel cells with a focus on five categories: carbides, oxides, nitrides, borides, and composites.

\section{Carbides}

The interest in metal carbides in recent years mostly rose from their possible use as catalytic materials. Some similarities between the catalytic behavior of tungsten carbide and platinum was found by Levy and Bourdart [17]. Others have shown studies on the catalytic activity of molybdenum and tungsten carbides as catalysts for methane reforming [18]. The attractiveness of these ceramic materials as catalysts was 
attributed to their high activity [19-21], lower price when compared to precious metals [22], unique structure [23], and stability [24] in acidic and alkaline mediums. In order for these materials to be good supports for electro-catalysts, they need to have high surface area (equivalent to $300 \mathrm{~m}^{2} / \mathrm{g}$ of carbon; with ceramic supports, this surface area may be much lower due to the atomic weight of the metals and comparisons should be made carefully) and good electrical conductivity (circa $4 \mathrm{~S} / \mathrm{cm}$ ) [25]. These requirements narrowed the possible candidates to a handful.

One of the most studied carbide supports is tungsten carbide. Ticianelli et al. [26] recently reported a composite of tungsten carbide/carbon (WC/C) synthesized using a chemical vapor deposition (CVD), and used it as a support for Pt in PEMFC anodes. They showed enhanced corrosion resistance when compared with Vulcan XC-72. Roman-Leshkov et al. [23] developed a removable ceramic coating method for the synthesis of WC. Using this technique, they were able to produce high-surface-area, electronically conductive WC, which also exhibited superior stability on the anode when compared to Vulcan XC-72. The electronic interaction between Pt and WC and its effect on the catalysis of the oxygen reduction reaction were also studied. It was concluded that the Pt is strongly attached to the support and that the interaction between the two promoted a favorable catalytic activity for the oxygen reduction reaction (ORR) [27]. Although very interesting, in these studies and others that showed similar trends [28], the WC was not exposed to harsh oxidizing conditions and was only studied at the anode where carbon corrosion is less of an issue [29]. Hence, so far, there is not enough information regarding the WC stability under oxidizing conditions.

A different carbide support was recently proposed by Elbaz et al. [30], who used the polymer-assisted deposition (PAD) method developed for the synthesis of nanoparticles by Jia et al. [31], for the synthesis of molybdenum carbide. They were able to form a $\mathrm{Mo}_{2} \mathrm{C} / \mathrm{C}$ composite which, similarly to the $\mathrm{WC}$, showed enhanced catalytic activity to ORR. Although their composite material was not completely resistant to corrosion, it did perform better than XC-72. They tied the loss of Pt electrochemical surface area (ECSA) on the $\mathrm{Mo}_{2} \mathrm{C} / \mathrm{C}$ during their accelerated stress tests (ASTs) to the presence of excess amorphous carbon. In a more recent publication [32], the authors synthesized amorphous carbon-free $\mathrm{Pt} / \mathrm{Mo} 2 \mathrm{C}$, which was found to be very resistant to corrosion, as shown in Figure 3 (less than 10\% loss of ECSA vs. 90\% with $\mathrm{Pt} / \mathrm{XC}-72)$. In this case the Pt was added to the support during its synthesis and formed non-crystalline small atomic clusters (3-6 atoms of Pt), which the authors called Nano Rafts. This new system exhibited remarkable ORR activity with a 50\% higher mass activity and a higher onset potential, attributed to the electronic interaction between the Pt and the support.

Titanium carbide has previously been tested as a support material of Ir for hydrogen evolution [33] and as a support of Pt for the electro-oxidation of methanol [34], both in acidic media, and showed promising results electrochemically and even in alleviating $\mathrm{CO}$ poisoning.

Recently, some studies were published also showing better durability of Pt supported on TiC than Pt/CB under ADTs (0.6-1.2V in 0.1 $\mathrm{M} \mathrm{HClO}_{4}$ solution) [35] and $\mathrm{Pt}_{3} \mathrm{Pd} / \mathrm{TiC} @ \mathrm{TiO}_{2}$ support [36], which even exceeds that of $\mathrm{Pt} / \mathrm{TiC}$ (under 0.4-1.2V), attributed to the corrosion resistance of the supports. 


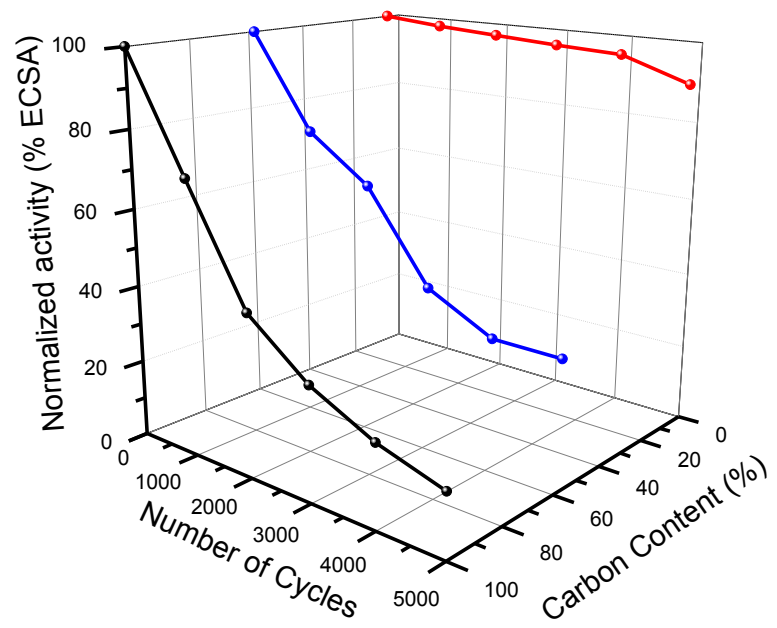

Figure 3. Normalized activity of $\mathrm{Pt} / \mathrm{C}$ (black), $\mathrm{Pt} / \mathrm{Mo}_{2} \mathrm{C} / \mathrm{C}$ (blue), and $\mathrm{Pt} / \mathrm{Mo}_{2} \mathrm{C}$ (red) as a function of the number of accelerated test cycles and carbon content.

\section{Oxides}

Metal Oxides are inorganic compounds that possess several compatible properties for FC applications. Exhibiting properties such as corrosion resistance and mechanical and thermal stability, they show a lot of potential for FCs, although some of them are only semi-conductors or even poor electrical conductors and require certain modifications in order to make sufficient FC materials.

\subsection{Titanium Oxide}

Titanium oxides received extensive interest in recent years and can be roughly divided into two groups: semi- or non-conducting systems (such as $\mathrm{TiO}_{2}$ ) and systems that show high electrical conductivity ( $\mathrm{Ti}_{n} \mathrm{O}_{2 n-1}$ group).

$\mathrm{Ti}_{n} \mathrm{O}_{2 n-1}$ (where $\mathrm{n}$ is between 4 and 10) is widely used in photo-catalysis [37-39], water splitting [40], and gas sensing [41] and has attracted much attention in the FC field as a possible catalyst support due to its relatively good conductivity. Recently, $\mathrm{Ti}_{n} \mathrm{O}_{2 n-1}$ has shown promising effects on the durability and catalytic activity of fuel cell catalysts because of its good mechanical resistance and stability in acidic and oxidative environments. Among this series of distinct oxides, $\mathrm{Ti}_{4} \mathrm{O}_{7}$ (titanium sub-oxide, $\mathrm{TSO}$ ) exhibits the highest electrical conductivity, exceeding $1000 \mathrm{~S} / \mathrm{cm}$ at $25^{\circ} \mathrm{C}$ [41].

In a recent study, $\mathrm{Wu}$ et al. [42] prepared $\mathrm{Ti}_{n} \mathrm{O}_{2 n-1}$ (magneli-phase TSO) and XC-72 to support $\mathrm{Pt}$ electro-catalysts for comparison purposes, both loaded with $20 \%$ wt Pt. Even though the TSO-based catalyst showed low conductivity $\left(\sim 10^{-3} \mathrm{~S} / \mathrm{cm} v s .4 .78 \mathrm{~S} / \mathrm{cm}\right.$ for XC-72 at $\left.12 \mathrm{MPa}\right)$, lower ECSA value $\left(13 \mathrm{~m}^{2} / \mathrm{g}\right.$ vs. $\left.30 \mathrm{~m}^{2} / \mathrm{g}\right)$, and minimally lower onset potential $(\Delta E=0.02 \mathrm{~V})$ compared to $\mathrm{Pt} / \mathrm{XC}-72$, their ADT procedure (cycling between -0.5 and $2.0 \mathrm{~V}$ vs. Saturated Calomel Electrode, SCE) was found to cause no change in the onset potential and minimal loss in ECSA (about 12\% vs. twice as much for Pt/XC-72) after 8000 cycles. TEM images proved that after 8000 cycles the $\mathrm{Pt} / \mathrm{XC}-72$ went through considerable $\mathrm{Pt}$ aggregation whereas the morphology of Pt/TSO remained intact. Ioroi et al. also studied Pt/TSO-based electrodes for PEMFC [43-45]. Although promising, one of the most significant issues that still remains 
unsolved with the sub-stoichiometric titanium oxide is its relatively low surface area which translates to lower current densities.

In this study, the synthesis, structure, and morphology of Pt/TSO using a laser-irradiated TSO support were investigated, as well as the electrochemical activity for ORR and its stability under high potential conditions for Pt/TSO. They found that the Pt/TSO catalyst had shown a specific activity for the oxygen reduction reaction (ORR) very similar to those of commercial $\mathrm{Pt} / \mathrm{C}$ catalysts, and much better oxidation resistance under high potential conditions as well. It was also shown that the conductivity of TSO-supported catalysts increased with an increase in Pt loading: $20 \mathrm{wt}$. \% Pt on TSO showed conductivity of $c a .8 \mathrm{~S} / \mathrm{cm}$ at $50 \mathrm{MPa}$, which was about one-quarter of that of $40 \mathrm{wt} \% \mathrm{Pt}$ on XC-72 $(30 \mathrm{~S} / \mathrm{cm})$ under the same conditions. On the other hand, the calculated ECSA of Pt/TSO was rather small compared to that of $\mathrm{Pt} / \mathrm{XC}-72$ (values of 22 and $16 \mathrm{~m}^{2} / \mathrm{g}$ for 10 wt. $\%$ and 20 wt. $\%$ vs. $44 \mathrm{~m}^{2} / \mathrm{g}$ for $\mathrm{Pt} / \mathrm{XC}-72$ ), indicating a larger diameter of deposited Pt particles, which was consistent with the results of SEM and TEM observations: the Pt particle diameter was between 10 and $20 \mathrm{~nm}$, which is much larger than the common $\mathrm{Pt} / \mathrm{C}$ catalysts. The performance of the $\mathrm{Pt} / \mathrm{Ti}_{4} \mathrm{O}_{7}$ cathode was evidently low compared to that of $20 \% \mathrm{Pt} / \mathrm{XC} 72$, mainly due to the smaller ECSA.

Non-stoichiometric mixtures of several titanium oxide phases, mainly $\mathrm{Ti}_{4} \mathrm{O}_{7}$ and $\mathrm{Ti}_{5} \mathrm{O}_{9}$, known as magneli-phase and by the registered name Ebonex, were investigated as well [46]. Ebonex is considered to be electrochemically stable with a tendency for ORR in acid and base solutions, possesses a high electrical conductivity of $1000 \mathrm{~S} / \mathrm{cm}$, and could be a good alternative catalyst support material [41,47]. The Pt/Ebonex catalytic activity was reported to be as much as 10 times higher than that of pure Pt. This was attributed to the increase of active Pt surface area by the reduction of Pt particles sized even below $1 \mathrm{~nm}$ and the increase of the number of active sites for oxygen reduction through simple geometric effects, as well as change of oxygen adsorption conditions through the change of the electronic structure of the catalyst caused by the electronic interactions between platinum and the Ebonex. These interactions were rationalized by the Ebonex's hypo-d-electron character which has the ability to interact with Pt that has the hyper-d-electron character. This synergetic effect was explained through the increase of the $5 \mathrm{~d}$ vacancy of $\mathrm{Pt}$ and the decrease of the Pt-Pt bond distances as a result of the interaction with Ebonex, which inhibits the chemisorption of $\mathrm{OH}^{-}$. It also shifts the $\mathrm{PtOH}$ formation to more positive potentials, facilitating the interaction of oxygen with $\mathrm{Pt}$, hence increasing the activity of the catalyst for the oxygen reduction reaction.

Another titanium oxide which was studied as a possible catalyst support for FCs is $\mathrm{TiO}_{2}$. It is a wide band gap semiconductor and its conductivity is insufficient for a support material without modification such as doping [48-51]. In spite of that, it was widely studied as a ceramic support promoting ORR in PEMFC. In a recent study [13], the synthesis of high surface area $\mathrm{TiO}_{2}$ and $\mathrm{TiO}$ composite materials in a single step was presented. The high surface area conductive titanium oxide was successfully synthesized using the polymer-assisted deposition technique [31]. The $\mathrm{TiO}_{2}$ and $\mathrm{TiO}$ nano-crystalline materials were formed with an average crystallite size on the order of 4 and $8 \mathrm{~nm}$ and a BET surface area of 286 and 200 $\mathrm{m}^{2} / \mathrm{g}$ for $\mathrm{TiO}$ and $\mathrm{TiO}_{2}$, respectively. Pt was added to the supports, and the calculated ECSA value also showed promise with approximately $60 \mathrm{~m}^{2} / \mathrm{g}$ for both phases. This system exhibited better ORR activity when compared to $\mathrm{Pt} / \mathrm{XC}-72$. This was again, as in the case of the sub-stoichiometric titanium oxides, attributed to the electronic interaction between the support and the Pt catalyst.

Shanmugam et al. [14] synthesized mesoporous $\mathrm{TiO}_{2}$ using the sono-chemical method. This synthesis resulted in a spherical globular morphology of the $\mathrm{TiO}_{2}$ particles, and a size range of 100-200 nm with 
pores of 4-7 nm which were around the size of the Pt particles deposited. This $\mathrm{Pt} / \mathrm{TiO}_{2}$ was compared to $\mathrm{Pt} / \mathrm{C}$. The onset potential of the oxide formation on the $\mathrm{Pt} / \mathrm{TiO}_{2}$ was shifted toward a higher potential, indicating a better resistance nature of $\mathrm{Pt} / \mathrm{TiO}_{2}$ for $\mathrm{Pt}-\mathrm{OH}$ formation. The $\mathrm{Pt} / \mathrm{TiO}_{2}$ also exhibited superior results towards ORR electro-catalysis than $\mathrm{Pt} / \mathrm{C}$. This enhanced activity is attributed to several factors, such as high dispersion, better stabilization, and the modification of the electronic structure of $\mathrm{Pt}$ nanoparticles by interaction with the oxide interface, which results in a change in the adsorption characteristics of $\mathrm{Pt}$ nanoparticles on $\mathrm{TiO}_{2}$. They also studied the stability examined by chronoamperometry at an applied voltage of $0.55 \mathrm{~V}$ and found that the current decay rate was higher for $\mathrm{Pt} / \mathrm{C}$ than for $\mathrm{Pt} / \mathrm{TiO}_{2}$ when only $13 \%$ decay was detected after $1 \mathrm{~h}(80 \%$ for conventional $\mathrm{Pt} / \mathrm{C})$. Several more studies were conducted with titanium oxide supports and showed very similar results [52-55].

\subsection{Tungsten Oxide}

Tungsten oxide is an n-type semiconductor with a band gap of a few eVs. Tungsten, which has several oxidation states (usually 2 to 6 ), appears in many forms, making it compatible with various applications. The conductivity of tungsten oxide comes from its non-stoichiometric composition, causing a donor level formed by oxygen-vacancy defects in the lattice.

Tungsten oxides (predominantly $\mathrm{WO}_{3}$ ) were studied for quite a long time as a catalyst for DMFC and showed high catalytic activity toward methanol oxidation reaction, possibly due to the formation of tungsten bronzes favoring the dehydrogenation of methanol, and a synergistic effect leading to $\mathrm{CO}$ tolerance [56-58]. Park et al. [59] showed excellent performance for the use of porous tungsten oxide in thin film fuel cells and also showed good stability in sulfuric acid. In another study [60], Pt was added to commercially available tungsten oxide. The performance of this system was compared to $\mathrm{Pt} / \mathrm{XC}-72$ and showed very high stability in acidic conditions.

Nano-sized $\mathrm{WO}_{3}$ was also studied as a possible support material for monolayer Pt ORR electro-catalysts in acid electrolyte [61]. Pt/ $\mathrm{WO}_{3}$ exhibited good activity for ORR and superior electron transfer capability compared to conventional $\mathrm{Pt} / \mathrm{C}$ and Pt. However, a thorough examination of the $\mathrm{WO}_{3}$ support revealed that it can easily turn to water-soluble hydrogen tungsten bronze $\left(\mathrm{H}_{x} \mathrm{WO}_{3}\right)$, facilitating the detachment of Pt nanoparticles as also been discussed elsewhere [62].

Recently, Lu et al. [63] studied the electrochemistry, structure, and interaction of nano-sheets of $\mathrm{Pd}$ on tungsten oxide ( $\left.\mathrm{Pd} / \mathrm{W}_{18} \mathrm{O}_{49}\right)$, comparing it to three other systems: $\mathrm{Pt} / \mathrm{C}, \mathrm{Pd} / \mathrm{C}$ (both obtained commercially), and support-less $\mathrm{Pd}$ NPs. The $\mathrm{Pd} / \mathrm{W}_{18} \mathrm{O}_{49}$ was found to have considerably higher electrical conductivity than the support devoid of Pd and had a higher surface area $\left(40 v s .30 \mathrm{~m}^{2} / \mathrm{g}\right)$. Electrochemical studies of ORR catalysis and accelerated life tests in alkaline media showed fairly remarkable results of the tungsten-based catalyst support, outperforming the other examined systems in almost every aspect $\left(\mathrm{ECSA}=48 \mathrm{~m}^{2} / \mathrm{g}\right.$, $E_{1 / 2}=0.875 \mathrm{~V} v s$. Reversible Hydrogen Electrode) and mass activity at $0.9 \mathrm{~V}-0.216 \mathrm{~A} / \mathrm{mg}_{\mathrm{pt}}$ ) and with very high stability of the $\mathrm{W}_{18} \mathrm{O}_{49}$ nano-sheets system.

Theoretical and experimental studies also revealed that oxygen has a higher affinity for Pd than Pt when on $\mathrm{W}_{18} \mathrm{O}_{49}$ [64], making $\mathrm{O}_{2}$ adsorb better on $\mathrm{Pd}$, enabling the $\mathrm{O}=\mathrm{O}$ bonds to break more easily. This causes a decrease in the electron density of $\mathrm{Pd}$, which weakens the Pd-O bond and could significantly increase the dissociation of $\mathrm{O}_{2}$. In fact, introducing $\mathrm{W}_{18} \mathrm{O}_{49}$, which substantially alters the electronic 
structure of $\mathrm{Pd}$, and the excess of oxygen vacancies present that might increase the electronic conductivity of $\mathrm{W}_{18} \mathrm{O}_{49}$ translated into enhanced electro-catalytic activity.

\subsection{Tin Oxide}

Tin oxide $\left(\mathrm{SnO}_{2}\right)$ is a post-transition metal dioxide with a structure resembling rutile $\mathrm{TiO}_{2}$, and is often referred to as an oxygen-deficient $n$-type semiconductor that has been studied in the fields of chemical sensors [65] and electronic devices [66].

$\mathrm{Pt}$ and $\mathrm{Pd}$ supported on $\mathrm{SnO}_{2}$ were investigated as catalyst systems for various chemical reactions, such as the low temperature oxidation of $\mathrm{CO}$ and methane [67], the reduction of NOxs [68], and the electro-oxidation of alcoholic fuels [69,70]. Indeed, pure tin dioxide is a wide band gap semiconductor with electrical conductivity varying from 0.1 to $10^{-6} \mathrm{~S} / \mathrm{cm}$. Therefore, if considered as a catalyst support for fuel cells, it must have higher conductivity and, hence, certain modifications such as doping [71-78] or distinct synthesis routes are required.

Various forms of tin oxide were reported, such as $\mathrm{SnO}_{2}$ nanowires [79] (TONW) synthesized by the thermal evaporation method and meso-porous tin oxide (MPTO) by the neutral-surfactant template-assisted method [80], having high BET surface area $\left(205 \mathrm{~m}^{2} / \mathrm{g}\right.$ for the MPTO, very close to the value of XC-72, ca. $230 \mathrm{~m}^{2} / \mathrm{g}$ ) and low particle size (20 nm diameter for TONWs and $6 \mathrm{~nm}$ for MPTO). After the addition of Pt to both supports, their ORR activity was compared with that of Pt on carbon and was found to be superior. In terms of durability and stability, the MPTO support outperformed commercial $\mathrm{Pt} / \mathrm{C}$ during potential cycling, including two steps: the first at a constant potential of $1.2 \mathrm{~V} v s$. RHE and the second between 0.6 and $1.2 \mathrm{~V} v s$. RHE in $0.5 \mathrm{M}$ sulfuric acid.

Other metal oxides that are still under investigation are $\mathrm{Pt} / \mathrm{MnO}_{2}$ [81] and $\mathrm{Pd} / \mathrm{Mn}_{2} \mathrm{O}_{3}$ [82], which have shown better catalytic activity than $\mathrm{Pt} / \mathrm{C}$ even with very low noble metal content, and $\mathrm{SiO}_{2}$ [83] and $\mathrm{NbO}_{2}$ [84], which were reported as ORR catalysts in fuel cells and have shown promising and interesting results.

\section{Nitrides}

Like metal oxides, metal nitrides have also attracted much attention owing to their excellent thermal and chemical stabilities. Recently, some of them were found to have catalytic properties similar to those of noble metals like Pd and Pt [85,86]. However, in terms of fuel cell applications, there have not been many publications dealing with metal nitrides as catalyst supports thus far.

Among these nitrides, TiN is the most studied since it seems to show the most promise. It has a high electrical conductivity of $\sim 4000 \mathrm{~S} / \mathrm{m}[87,88]$ and is considered to have good corrosion resistance, usually attributed to the oxy-nitride layer, caused by the formation on the surface oxide due to atmospheric oxidation and/or acidic media, which prevents further oxygen diffusion to the bulk [89], in turn making it relatively chemically inert.

However, corrosion still might occur under fuel cell conditions (relatively high temperature, acidic environment, oxygen presence, high water content, and high potential applications), turning TiN into oxide form which leads to catalyst particle growth and significantly lowers the conductivity [89]. Some have tried to use this to their advantage by making oxy-nitride supports [90], employing the high corrosion stability of $\mathrm{TiO}_{2}$ and the electrical conductivity of TiN. These supports with Pt deposited on them have 
shown to have an ECSA more than three times higher than the conventional Pt/C catalyst and the activity under prolonged operations (denoted by ECSA) exceeded 50\% even after 1000 cycles (close to $0 \%$ for $\mathrm{Pt} / \mathrm{C}$ under the same conditions). Another study on TiON [91] substantiated this increased stability and even showed an improved result of only $20 \%$ loss in ECSA after 1000 cycles ( $80 \%$ loss for Pt/C).

More complex morphologies of TiN were also synthesized in order to increase the surface area and lower the TiN content and overall weight. For example, Pan et al. [92] synthesized hollow TiN nanotubes (NTs) by two-step synthesis. The TiN hollow NTs showed better electrochemical activity and stabilty than comercial $\mathrm{Pt} / \mathrm{C}$ after an accelerated life test.

Since nitrides do not show any significant catalytic activity, a catalyst is usually added to the support. The interaction of the catalyst, in most cases - $\mathrm{Pt}$, with the support is of extreme interest, since the support may change the Pt-Pt bond length and the electron density on the Pt, hence changing its catalytic activity. Zhang et al. [93] investigated the thermodynamics of a single-atom Pt catalyst bonding to the TiN surface and found that Pt atoms prefer to be embedded on the surface of the TiN, at the N vacancy sites, instead of forming Pt clusters. Therefore, under typical PEM fuel cell operation, TiN surface vacancies come into play, anchoring the Pt atom for better catalytic function as illustrated in Figure 4.
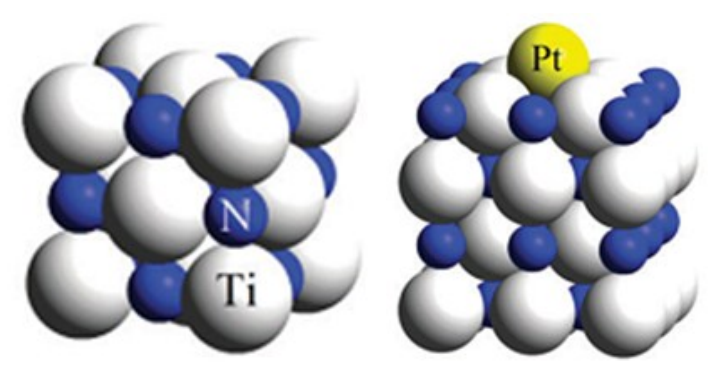

Figure 4. Crystal structure of TiN and the atomic structure model of Pt embedded on an $\mathrm{N}$-vacancy site [93] (adapted from this reference with the permission of RSC publishing).

Although showing good stability when compared to carbon supports, TiNs show degradation under fuel cell operating conditions. This was studied by Avasarala et al. $[89,94]$, who investigated the degradation mechanism of the Pt/TiN catalyst under fuel cell conditions using their accelerated stress test (AST) protocols. They found that out of the three main degradation mechanisms taken into account under these conditions, (1) support oxidation, (2) catalyst agglomeration, and (3) catalyst dissolution, Pt catalyst agglomeration and coalescence were the most dominant. Furthermore, during potential cycling, the oxy-nitride formed on the outer layer tends to dissolve to Ti (IV) hydroxide ions, leading to further passivation of the surface.

Among the other less-studied nitride supports, vanadium nitride (VN) has also been shown to have properties that might be suitable for fuel cells, such as reasonable surface area $\left(55.4 \mathrm{~m}^{2} / \mathrm{g}\right)$ and good electrical conductivity $(72 \mathrm{~S} / \mathrm{cm})$. It was studied as a support for $\mathrm{Pd}$ for formic acid fuel cells and has shown to be efficiently prepared by solid-solid phase separation. Higher catalytic activity promoting formic acid oxidation, dehydrogenation path, and diminished Pd catalyst CO poisoning was also demonstrated [95]. In addition, pure VN showed some catalytic activity for ORR [86], and was also suggested as a promising electrode material for electrochemical super-capacitors [96]. 
Another interesting nitride support is $\mathrm{Mo}_{2} \mathrm{~N}$, which was reported both as a catalyst substitute for Pt on carbon [85,97] and as a catalyst support [15]. In these studies, $\mathrm{Mo}_{2} \mathrm{~N}$ supports were prepared by polymer-assisted deposition, and subsequently, Pt nanoparticles were grown on it. The ECSA of the Pt was $20.8 \mathrm{~m}^{2} / \mathrm{g}$, lower than commercial Pt/C. Although not much work has been conducted with it, it has shown some initial potential and requires further research and improvement.

Other non-metal ceramics such as carbo-nitrides were also studied as combined catalyst-support arrays with noble and non-noble metals [98,99]. Xu et al. [100] reported the synthesis of graphitic $\mathrm{C}_{3} \mathrm{~N}_{4}$ support by the direct heating of dicyandiamide for the deposition of $\mathrm{Ag}$ nanoparticles as the catalyst, forming $\mathrm{Ag} / \mathrm{g}-\mathrm{C}_{3} \mathrm{~N}_{4}$. They came to the conclusion that this system showed fair ORR catalytic activity that remained almost unchanged after 200 cycles in oxygen atmosphere. $\mathrm{C}_{3} \mathrm{~N}_{4}$ was also examined for durability and showed inconclusive results.

\section{Composites/Hybrides}

Some ceramic supports possess good resistance to electrochemical oxidation and stability in acidic environments, which leads to the consideration of them as alternative catalyst supports. However, the low electrical conductivity of some of them may prevent their extensive application in fuel cells.

\subsection{Carbon-Based Ceramic Composites}

Carbon has high electrical conductivity and surface area, therefore it has been introduced into ceramic supports physically and/or synthetically in order to improve supports that are lacking some or both of these critical properties. However, adding carbon may also lower the composite materials' corrosion resistance and enhance the supports' degradation in fuel cells. Therefore, ceramics that contain carbon might possess both carbon-like and ceramic-like properties, improving the support's compatibility for fuel cells but causing it to be more susceptible to corrosion.

$\mathrm{Pd}$ catalyst on iron-molybdenum-carbon $\left(\mathrm{Fe}_{2} \mathrm{MoC}\right)$ composite was synthesized and then compared electrochemically to conventional $\mathrm{Pt} / \mathrm{C}, \mathrm{Pd} / \mathrm{C}$, and $\mathrm{Pd} / \mathrm{MoC}$ catalysts [101]. The ORR onset potential of the $\mathrm{Pd}$ on the composite support was much higher when compared to $\mathrm{Pd} / \mathrm{C}$ and $\mathrm{Pd} / \mathrm{MoC}$, but it did not demonstrate much improvement when compared to $\mathrm{Pt} / \mathrm{C}$. However, the calculated mass activity did show detectable improvement for the $\mathrm{Pd} / \mathrm{Fe}_{2} \mathrm{MoC}$ compared to the $\mathrm{Pt} / \mathrm{C}$ (146.4 and $124.3 \mathrm{~mA} / \mathrm{mg}_{\text {cat }}$, respectively), in spite of a smaller catalyst loading ratio (37.6\% and $47.6 \%$, respectively). In addition, it showed better stability when compared to $\mathrm{Pt} / \mathrm{C}$.

Some other carbon-based composite ceramics that were synthesized and examined for ORR performance are $\mathrm{Co}_{3} \mathrm{~W}_{3} \mathrm{C}$ [102] and $\mathrm{Co}_{6} \mathrm{Mo}_{6} \mathrm{C}_{2}$ [103]. Loaded with catalysts (Pd for the tungsten-based hybrid and Pt for the molybdenum-based), they were electrochemically characterized, and while the tungsten-based support exhibited only slightly better electrochemical characteristics such as onset potential, mass activity, and stability under prolonged exposure to an oxidizing environment compared with conventional $\mathrm{Pt} / \mathrm{C}$, the molybdenum-based support demonstrated substantial improvement in mass activity (more than twice the value of $\mathrm{Pt} / \mathrm{C}$ ) and showed a detectable improved stability with no detectable degradation during the AST (1000 CV cycles between 0.6-1.2V and 0.05-1.1V vs. RHE, respectively, in $\mathrm{O}_{2}$-saturated $0.1 \mathrm{M} \mathrm{HClO}_{4}$ solution). 
Tungsten carbide and carbon nanotubes (CNTs) have exhibited ORR catalytic activity with a noble metal catalyst separately $[9,10,12,104]$. Considering that a hybrid tungsten carbidelCNTs was synthesized and tested by Liang et al. [105], even with half the Pt loading, the Pt/WC-CNT electro-catalyst had a higher onset potential compared to the Pt/CNT, indicating a synergistic effect between Pt, WC, and the CNTs. Different composites of WC/C were reported. Garcia \& Ticianelli [106] mixed tungsten hexacarbonyl with Vulcan XC-72. They tested different samples of the support for ORR activity. The supports were distinguished by the $\mathrm{WC}$ to $\mathrm{C}$ ratio in the presence of $\mathrm{W}_{2} \mathrm{C}$. They found that all samples had better catalytic activity (denoted by onset potentials and specific activity) compared to $\mathrm{Pt} / \mathrm{C}$ due to an increase of the $\mathrm{Pt}$ 5d-band occupancy, which led to a weaker $\mathrm{Pt}-\mathrm{OH}$ interaction, resulting in a lower Pt-oxide coverage and thus increasing the kinetics of ORR.

The electrochemical properties and application of tungstate salts such as $\mathrm{SrWO}_{4}$ and $\mathrm{CaWO}_{4}$ mixed with graphite were investigated as well [107,108]. Both catalysts exhibited better electrochemical activity for oxygen reduction reaction in $\mathrm{H}_{2} \mathrm{SO}_{4}$ solution compared to $\mathrm{Pt} /$ graphite, denoted by the onset potential for $\mathrm{SrWO}_{4}\left(0.65 \mathrm{~V} v s .0 .55 \mathrm{~V}\right.$ for Pt/graphite) and the half-wave potential for $\mathrm{CaWO}_{4}(0.51 \mathrm{~V} v s .0 .45 \mathrm{~V}$ for $\mathrm{Pt} /$ graphite).

\subsection{Other Ceramic Composites}

Other composites that do not contain carbon and are usually based on more than one metal were reported as well. An interesting cesium- and tungsten-based composite that has formerly been reported as an electrolyte for fuel cells [109] due to their good proton conductivity and stability was examined in PEMFC [110]. The $\mathrm{Cs}_{2.5} \mathrm{H}_{0.5} \mathrm{PW}_{12} \mathrm{O}_{40}$ was shown to have a relatively high surface area $\left(136 \mathrm{~m}^{2} / \mathrm{g}\right)$ diminished to $35-50 \mathrm{~m}^{2} / \mathrm{g}$ after the addition of $\mathrm{Pt}$, suggesting $\mathrm{Pt}$ saturation of the low dimension pores. The composite also showed better catalytic activity and stability in acidic media than conventional Pt/XC-72, which was attributed to the pores preventing Pt agglomeration.

The widely used indium tin oxide (ITO) is an n-type semiconductor with a wide band gap, which is produced by replacing $\mathrm{In}^{3+}$ by $\mathrm{Sn}^{4+}$ in the cubic structure of indium oxide. This replacement produces free electrons enhancing its conductivity and, thus, influences the optical and electrical properties of the ITO film [111]. ITO is a commercially available material often used as a transparent conducting oxide (TCO) for smart windows. Chhina et al. [112] fabricated a Pt/ITO catalyst as a potential non-carbon catalyst support and investigated the thermal and electrochemical stability. The Pt on ITO had an average crystallite size of $13 \mathrm{~nm}$. Electrochemical measurements indicated that this catalyst was much more stable than those of both commercially available Hispec 4000 and Pt/XC-72R. In a different study [113], Pt clusters were deposited on the ITO NPs through the galvanic displacement of Cu by Pt. The specific ECSA of Pt/ITO $\left(83.1 \mathrm{~m}^{2} / \mathrm{g}\right)$ was found to be three times that of $\mathrm{Pt} / \mathrm{C}\left(27.3 \mathrm{~m}^{2} / \mathrm{g}\right)$ and, after 1000 cycles, changes in the $\mathrm{Pt}$ ECSA and electrocatalytic activity proved the stability of the Pt/ITO catalyst was far superior to that of $\mathrm{Pt} / \mathrm{C}$ when Pt/ITO showed no recordable loss of Pt ECSA. However, for Pt/C, only $\sim 65 \%$ of the original ECSA remained after potential cycling. However, TEM pictures taken after the stability tests detected several small holes on the ITO surface due to the corrosion and dissolution of the surface Sn. 


\section{Titanium Diboride}

$\mathrm{TiB}_{2}$ is a relatively novel titanium-based support that has been considered as a base material for a range of different applications. It exhibits good electrical $\left(\sim 10^{5} \mathrm{~S} / \mathrm{cm}\right)$ and high thermal conductivity $(\sim 65$ $\mathrm{W} / \mathrm{mK}$ ), excellent thermal stability and corrosion resistance in acidic medium [114], and might be considered a promising candidate for PEMFC catalyst ceramic support.

$\mathrm{TiB}_{2}$ was first reported in the context of fuel cells by Yin et al. $[115,116]$, who deposited Pt particles on $\mathrm{TiB}_{2}$ support by colloidal route. Before then, it was reported that smaller particle size leads to the agglomeration of particles and the loss of ECSA due to a higher specific surface energy. Using their synthesis route, the highly dispersed Pt nanoparticles on the ceramic support were dispersed and stabilized by Nafion in order to prevent agglomeration and particle growth. Indeed, the ceramic boride showed similar catalytic activity (similar onset potential) in addition to better durability when compared to conventional Pt/C after 6000 cycles of CVs in $0.5 \mathrm{M}$ sulfuric acid. About $60 \%$ loss of ECSA was exhibited while about $80 \%$ loss was detected for $\mathrm{Pt} / \mathrm{C}$ after 5000 cycles.

The electrochemical stability of the $\mathrm{Pt} / \mathrm{TiB}_{2}$ catalyst was approximately four times higher than that of the commercial $\mathrm{Pt} / \mathrm{C}$ catalyst after cycling between 0 and $1.2 \mathrm{~V}$ in $0.5 \mathrm{M} \mathrm{H}_{2} \mathrm{SO}_{4}$, due to the support characteristics and also possibly from the Nafion stabilization effects, which enhanced both the metal support interaction and the steric hindrance effect of the surface Pt nanoparticles. In several other studies, $\mathrm{Pt} / \mathrm{TiB}_{2}$ was obtained not only by colloidal route [115-117] but also by carbo-thermal reduction $[118,119]$.

Huang et al. [117] investigated the effect of several kinds of pretreatments applied to the support (mostly exposing it to acidic or alkaline media), in an attempt to reduce the influence of $\mathrm{TiB}_{2}$ particle size on the electrochemical performance of the system. The study showed that among the investigated pretreatments, the hydrogen peroxide pretreatment demonstrated the best results, producing a catalyst with about twice the ECSA compared to other pretreated samples, possibly due to the presence of $\mathrm{TiO}_{2}$. However, Roth et al. [118] deposited Pt particles on $\mathrm{TiB}_{2}$ prepared via the carbo-thermal reduction method [116], and showed that although $\mathrm{TiB}_{2}$ exhibited good stability under normal cycling, its performance, denoted by power density, reduced much more rapidly (it showed less than half the power density after only 100 cycles) under actual fuel cell conditions (oxygen presence and an elevated temperature of $80^{\circ} \mathrm{C}$ ), claimed to be due to oxide formation which probably led to reduced conductivity.

\section{Conclusions}

Corrosion is a serious issue in fuel cell technology as it can dramatically reduce the electrode life time, and thus the overall performance of the cell. In order to try to increase the lifetime of the electrodes, various materials have been proposed, the most promising of which are the ceramic materials. In most cases, carbides, oxides, nitrides, borides, and composite materials have shown better stability and durability when compared to the commercially available standard, Pt/XC-72. Unfortunately, due to the lack of standard protocols for the assessment of these parameters, it is impossible to compare between supports and tell which is best under certain conditions.

One very interesting outcome, which most of the researchers in the field seem to agree upon, is that the move from carbon to other supports opens up a wide array of possibilities when it comes to catalyst activity. In fact, in many of the studies surveyed in this review, enhancement of the catalytic properties 
was shown and was attributed to the favorable interaction of the catalysts, in most cases - Pt, with the support. When choosing ceramic supports for fuel cells, one must consider their conductivity, which in some cases is very low when compared to carbon supports, and the surface area of the support. The latter is an issue that most studies do not tackle yet, but may impact the overall performance significantly.

\section{Acknowledgments}

The authors would like to thank MAFAT for funding this work.

\section{Author Contributions}

Oran Lori and Lior Elbaz wrote this review together with equal contribution. Oran Lori was responsible for revising it and Lior Elbaz edited its final version.

\section{Conflicts of Interest}

The authors declare no conflict of interest.

\section{References}

1. Borup, R.; Meyers, J.; Pivovar, B.; Kim, Y.S.; Mukundan, R.; Garland, N.; Myers, D.; Wilson, M.; Garzon, F.; Wood, D. Scientific aspects of polymer electrolyte fuel cell durability and degradation. Chem. Rev. 2007, 107, 3904-3951.

2. Meier, J.C.; Galeano, C.; Katsounaros, I.; Witte, J.; Bongard, H.J.; Topalov, A.A.; Baldizzone, C.; Mezzavilla, S.; Schueth, F.; Mayrhofer, K.J.J. Design criteria for stable pt/c fuel cell catalysts. Beilstein J. Nanotechnol. 2014, 5, 44-67.

3. Pourbaix, M. Atlas of Electrochemical Equilibria in Aqueous Solutions; National Association of Corrosion: Oxford, UK 1974.

4. Barth, T.; Lunde, G. The lattice constants of metallic platinum, silver and gold. Z. Phys. Chem. 1926, 121, 78-102.

5. Clougherty, E.V.; Lothrop, K.H.; Kafalas, J.A. New phase formed by high-pressure treatment. Nature 1961, doi:10.1038/1911194a0.

6. Rudy, E.; Windisch, S.; Stosick, A.J.; Hoffman, J.R. The constitution of binary molybdenum-carbon alloys. AIME 1967, 239, 1247-1267.

7. Gruver, G.A. Corrosion of Carbon-black in Phosphoric-acid. J. Electrochem. Soc. 1978, 125, 1719-1720.

8. Meyers, J.P.; Darling, R.M. Model of carbon corrosion in PEM fuel cells. J. Electrochem. Soc. 2006, 153, A1432-A1442.

9. Li, W.; Wang, X.; Chen, Z.; Waje, M.; Yan, Y. Pt-Ru Supported on Double-Walled Carbon Nanotubes as High-Performance Anode Catalysts for Direct Methanol Fuel Cells. J. Phys. Chem. B 2006, 110, 15353-15358.

10. Wu, G.; Xu, B.-Q. Carbon nanotube supported Pt electrodes for methanol oxidation: A comparison between multi- and single-walled carbon nanotubes. J. Power Sources 2007, 174, 148-158. 
11. Zhou, X.; Qiao, J.; Yang, L.; Zhang, J. A Review of Graphene-Based Nanostructural Materials for Both Catalyst Supports and Metal-Free Catalysts in PEM Fuel Cell Oxygen Reduction Reactions. Adv. Energy Mater. 2014, 4, 1301523:1-1301523:25.

12. Wang, X.; Li, W.; Chen, Z.; Waje, M.; Yan, Y. Durability investigation of carbon nanotube as catalyst support for proton exchange membrane fuel cell. J. Power Sources 2006, 158, 154-159.

13. Armstrong, K.J.; Elbaz, L.; Bauer, E.; Burrell, A.K.; McCleskey, T.M.; Brosha, E.L. Nanoscale titania ceramic composite supports for PEM fuel cells. J. Mater. Res. 2012, 27, 2046-2054.

14. Shanmugam, S.; Gedanken, A. Synthesis and electrochemical oxygen reduction of platinum nanoparticles supported on mesoporous $\mathrm{TiO}_{2}$. J. Phys. Chem. C 2009, 113, 18707-18712.

15. Blackmore, K.J.; Elbaz, L.; Bauer, E.; Brosha, E.L.; More, K.; McCleskey, T.M.; Burrell, A.K. High Surface Area Molybdenum Nitride Support for Fuel Cell Electrodes. J. Electrochem. Soc. 2011, 158, B1255-B1259.

16. Cui, X.; Guo, L.; Cui, F.; He, Q.; Shi, J. Electrocatalytic activity and co tolerance properties of mesostructured pt/wo3 composite as an anode catalyst for pemfes. J. Phys. Chem. C 2009, 113, 4134-4138.

17. Levy, R.B.; Boudart, M. Platinum-like behavior of tungsten carbide in surface catalysis. Science 1973, 181, 547-549.

18. York A.P.E.; Claridge J.B.; Brungs A.J.; Brungs, A.J.; Tsang, S.C.; Green, M.L.H. Molybdenum and tungsten carbides as catalysts for the conversion of methane to synthesis gas using stoichiometric feedstocks. Chem. Commun. 1997, 39-40.

19. Burns, S.; Gallagher, J.G.; Hargreaves, J.S.J.; Harris, P.J.F. Direct observation of carbon nanotube formation in $\mathrm{Pd} / \mathrm{H}-\mathrm{ZSM}-5$ and $\mathrm{MoO}_{3} / \mathrm{H}-\mathrm{ZSM}-5$ based methane activation catalysts. Catal. Lett. 2007, 116, 122-127.

20. Ribeiro, F.H.; Boudart, M.; Dalla Betta, R.A.; Iglesia, E. Catalytic reactions of $n$-Alkanes on $\beta-\mathrm{W}_{2} \mathrm{C}$ and $\mathrm{WC}$ : The effect of surface oxygen on reaction pathways. J. Catal. 1991, 130, 498-513.

21. Ledoux, M.J.; Huu, C.P.; Guille, J.; Dunlop, H. Compared activities of platinum and high specific surface area $\mathrm{Mo}_{2} \mathrm{C}$ and $\mathrm{WC}$ catalysts for reforming reactions: I. Catalyst activation and stabilization: Reaction of $n$-hexane. J. Catal. 1992, 134, 383-398.

22. Esposito, D.V.; Chen, J.G. Monolayer platinum supported on tungsten carbides as low-cost electrocatalysts: opportunities and limitations. Energy Environ. Sci. 2011, 4, 3900-3912.

23. Hunt, S.T.; Nimmanwudipong, T.; Román-Leshkov, Y. Engineering Non-sintered, Metal-Terminated Tungsten Carbide Nanoparticles for Catalysis. Angew. Chem. Int. Ed. 2014, 53, 5131-5136.

24. Curry, K.E.; Thompson, L.T. Carbon-hydrogen bond activation over tungsten carbide catalysts. Catal. Today 1994, 21, 171-184.

25. Pantea, D.; Darmstadt, H.; Kaliaguine, S.; Sümmchen, L.; Roy, C. Electrical conductivity of thermal carbon blacks: Influence of surface chemistry. Carbon 2001, 39, 1147-1158.

26. Hassan, A.; Paganin, V.A.; Ticianelli, E.A. Pt modified tungsten carbide as anode electrocatalyst for hydrogen oxidation in proton exchange membrane fuel cell: $\mathrm{CO}$ tolerance and stability. Appl. Catal. B 2015, 165, 611-619. 
27. Poh, C.K.; Lim, S.H.; Lin, J.; Feng, Y.P. Tungsten Carbide Supports for Single-Atom Platinum-Based Fuel-Cell Catalysts: First-Principles Study on the Metal-Support Interactions and $\mathrm{O}_{2}$ Dissociation on $\mathrm{W}_{x} \mathrm{C}$ Low-Index Surfaces. J. Phys. Chem. C 2014, 118, 13525-13538.

28. Nikolic, V.M.; Perovic, I.M.; Gavrilov, N.M.; Pašti, I.A.; Saponjic, A.B.; Vulic, P.J.; Karic, S.D.; Babic, B.M.; Marceta Kaninski, M.P. On the tungsten carbide synthesis for PEM fuel cell application-Problems, challenges and advantages. Int. J. Hydrogen Energy 2014, 39, 11175-11185.

29. Tang, H.; Qi, Z.; Ramani, M.; Elter, J.F. PEM fuel cell cathode carbon corrosion due to the formation of air/fuel boundary at the anode. J. Power Sources 2006, 158, 1306-1312.

30. Elbaz, L.; Kreller, C.R.; Henson, N.J.; Brosha, E.L. Electrocatalysis of oxygen reduction with platinum supported on molybdenum carbide-carbon composite. J. Electroanal. Chem. 2014, 720-721, 34-40.

31. Jia, Q.X.; McCleskey, T.M.; Burrell, A.K.; Lin, Y.; Collis, G.E.; Wang, H.; Li, A.D.Q.; Foltyn, S.R. Polymer-assisted deposition of metal-oxide films. Nat. Mater. 2004, 3, 529-532.

32. Elbaz, L.; Phillips, J.; Artyushkova, K.; More, K.; Brosha, E.L. Evidence of High Electrocatalytic Activity of Molybdenum Carbide Supported Platinum Nanorafts. J. Electrochem. Soc. 2015, 162, H681-H685.

33. Ma, L.; Sui, S.; Zhai, Y. Preparation and characterization of Ir/TiC catalyst for oxygen evolution. J. Power Sources 2008, 177, 470-477.

34. Ou, Y.; Cui, X.; Zhang, X.; Jiang, Z. Titanium carbide nanoparticles supported Pt catalysts for methanol electrooxidation in acidic media. J. Power Sources 2010, 195, 1365-1369.

35. Chiwata, M.; Kakinuma, K.; Wakisaka, M.; Uchida, M.; Deki, S.; Watanabe, M.; Uchida, H. Oxygen Reduction Reaction Activity and Durability of Pt Catalysts Supported on Titanium Carbide. Catalysts 2015, 5, 966-980.

36. Ignaszak, A.; Song, C.; Zhu, W.; Zhang, J.; Bauer, A.; Baker, R.; Neburchilov, V.; Ye, S.; Campbell, S. Titanium carbide and its core-shelled derivative $\mathrm{TiC} @ \mathrm{TiO}_{2}$ as catalyst supports for proton exchange membrane fuel cells. Electrochim. Acta 2012, 69, 397-405.

37. Toyoda, M.; Yano, T.; Tryba, B.; Mozia, S.; Tsumura, T.; Inagaki, M. Preparation of carbon-coated Magneli phases $\mathrm{Ti}_{n} \mathrm{O}_{2 n-1}$ and their photocatalytic activity under visible light. Appl. Catal. B 2009, 88, 160-164.

38. Toyoda, M.; Yano, T.; Mozia, S.; Tsumura, T.; Itoh, E.; Amao, Y.; Inagaki, M. Development of visible-light sensitive reduced phases of titania, $\mathrm{Ti}_{n} \mathrm{O}_{2 n-1}$, through carbon coating. Tanso 2005 , 220, 265-269.

39. Ni, M.; Leung, M.K.; Leung, D.Y.; Sumathy, K. A review and recent developments in photocatalytic water-splitting using $\mathrm{TiO}_{2}$ for hydrogen production. Renewable Sustainable Energy Rev. 2007, 11, 401-425.

40. Zhu, Y.; Shi, J.; Zhang, Z.; Zhang, C.; Zhang, X. Development of a gas sensor utilizing chemiluminescence on nanosized titanium dioxide. Anal. Chem. 2002, 74, 120-124.

41. Bartholomew, R.F.; Frankl, D. Electrical properties of some titanium oxides. Phys. Rev. 1969, 187, doi: 10.1103/PhysRev.187.828.

42. Wu, Q.; Ruan, J.; Zhou, Z.; Sang, S. Magneli phase titanium sub-oxide conductive ceramic $\mathrm{Ti}_{n} \mathrm{O}_{2 n-1}$ as support for electrocatalyst toward oxygen reduction reaction with high activity and stability. J. Cent. South Univ. 2015, 22, 1212-1219. 
43. Ioroi, T.; Akita, T.; Yamazaki, S.-i.; Siroma, Z.; Fujiwara, N.; Yasuda, K. Corrosion-Resistant PEMFC Cathode Catalysts Based on a Magnéli-Phase Titanium Oxide Support Synthesized by Pulsed UV Laser Irradiation. J. Electrochem. Soc. 2011, 158, C329-C334.

44. Ioroi, T.; Senoh, H.; Siroma, Z.; Yamazaki, S.-i.; Fujiwara, N.; Yasuda, K. Stability of Corrosion-Resistant Magnéli-Phase $\mathrm{Ti}_{4} \mathrm{O}_{7}-S$ upported PEMFC Catalysts. ECS Trans. 2007, 11, 1041-1048.

45. Ioroi, T.; Siroma, Z.; Fujiwara, N.; Yamazaki, S.-i.; Yasuda, K. Sub-stoichiometric titanium oxide-supported platinum electrocatalyst for polymer electrolyte fuel cells. Electrochem. Commun. 2005, 7, 183-188.

46. Vračar, L.M.; Krstajić, N.V.; Radmilović, V.R.; Jakšić, M.M. Electrocatalysis by nanoparticles- oxygen reduction on Ebonex/Pt electrode. J. Electroanal. Chem. 2006, 587, 99-107.

47. Geng, P.; Su, J.Y.; Miles, C.; Comninellis, C.; Chen, G.H. Highly-Ordered Magneli Ti4 ${ }_{7}$ Nanotube Arrays as Effective Anodic Material for Electro-oxidation. Electrochim. Acta 2015, 153, 316-324.

48. Du, Q.; Wu, J.; Yang, H. Pt@, $\mathrm{Nb}-\mathrm{TiO}_{2}$ catalyst membranes fabricated by electrospinning and atomic layer deposition. ACS Catal. 2013, 4, 144-151.

49. Chevallier, L.; Bauer, A.; Cavaliere, S.; Hui, R.; Rozière, J.; Jones, D.J. Mesoporous nanostructured $\mathrm{Nb}$-doped titanium dioxide microsphere catalyst supports for PEM fuel cell electrodes. ACS Appl. Mater. Interfaces 2012, 4, 1752-1759.

50. Bauer, A.; Chevallier, L.; Hui, R.; Cavaliere, S.; Zhang, J.; Jones, D.; Rozière, J. Synthesis and characterization of $\mathrm{Nb}-\mathrm{TiO}_{2}$ mesoporous microsphere and nanofiber supported Pt catalysts for high temperature PEM fuel cells. Electrochim. Acta 2012, 77, 1-7.

51. Elezović, N.; Babić, B.; Gajić-Krstajić, L.; Radmilović, V.; Krstajić, N.; Vračar, L. Synthesis, characterization and electrocatalytical behavior of $\mathrm{Nb}-\mathrm{TiO}_{2} / \mathrm{Pt}$ nanocatalyst for oxygen reduction reaction. J. Power Sources 2010, 195, 3961-3968.

52. Siracusano, S.; Stassi, A.; Modica, E.; Baglio, V.; Aricò, A.S. Preparation and characterisation of Ti oxide based catalyst supports for low temperature fuel cells. Int. J. Hydrogen Energy 2013, 38, 11600-11608.

53. Huang, S.-Y.; Ganesan, P.; Popov, B.N. Titania supported platinum catalyst with high electrocatalytic activity and stability for polymer electrolyte membrane fuel cell. Appl. Catal. B 2011, 102, 71-77.

54. Ioroi, T.; Akita, T.; Asahi, M.; Yamazaki, S.; Siroma, Z.; Fujiwara, N.; Yasuda, K. Platinum-titanium alloy catalysts on a Magnéli-phase titanium oxide support for improved durability in Polymer Electrolyte Fuel Cells. J. Power Sources 2013, 223, 183-189.

55. Huang, D.; Zhang, B.; Bai, J.; Zhang, Y.; Wittstock, G.; Wang, M.; Shen, Y. Pt Catalyst Supported within $\mathrm{TiO}_{2}$ Mesoporous Films for Oxygen Reduction Reaction. Electrochim. Acta 2014, 130, 97-103.

56. Micoud, F.; Maillard, F.; Gourgaud, A.; Chatenet, M. Unique CO-tolerance of Pt-WO $\mathrm{W}_{x}$ materials. Electrochem. Commun. 2009, 11, 651-654.

57. Rajeswari, J.; Viswanathan, B.; Varadarajan, T.K. Tungsten trioxide nanorods as supports for platinum in methanol oxidation. Mater. Chem. Phys. 2007, 106, 168-174. 
58. Cui, X.; Shi, J.; Chen, H.; Zhang, L.; Guo, L.; Gao, J.; Li, J. Platinum/mesoporous $\mathrm{WO}_{3}$ as a carbon-free electrocatalyst with enhanced electrochemical activity for methanol oxidation. J. Phys. Chem. B 2008, 112, 12024-12031.

59. Park, K.W.; Ahn, K.S.; Choi, J.H.; Nah, Y.C.; Kim, Y.M.; Sung, Y.E. Pt-WO $x$ electrode structure for thin-film fuel cells. Appl. Phys. Lett. 2002, 81, 907-909.

60. Chhina, H.; Campbell, S.; Kesler, O. Ex situ Evaluation of Tungsten Oxide as a Catalyst Support for PEMFCs. J. Electrochem. Soc. 2007, 154, B533-B539.

61. Liu, Y.; Shrestha, S.; Mustain, W.E. Synthesis of Nanosize Tungsten Oxide and Its Evaluation as an Electrocatalyst Support for Oxygen Reduction in Acid Media. ACS Catal. 2012, 2, 456-463.

62. Jaksic, J.M.; Labou, D.; Papakonstantinou, G.D.; Siokou, A.; Jaksic, M.M. Novel spillover interrelating reversible electrocatalysts for oxygen and hydrogen electrode reactions. J. Phys. Chem. C 2010, 114, 18298-18312.

63. Lu, Y.; Jiang, Y.; Gao, X.; Wang, X.; Chen, W. Strongly Coupled Pd Nanotetrahedron/Tungsten Oxide Nanosheet Hybrids with Enhanced Catalytic Activity and Stability as Oxygen Reduction Electrocatalysts. J. Am. Chem. Soc. 2014, 136, 11687-11697.

64. Lima, F.H.B.; Zhang, J.; Shao, M.H.; Sasaki, K.; Vukmirovic, M.B.; Ticianelli, E.A.; Adzic, R.R. Catalytic Activity-d-Band Center Correlation for the $\mathrm{O}_{2}$ Reduction Reaction on Platinum in Alkaline Solutions. J. Phys. Chem. C 2007, 111, 404-410.

65. Fagan, J.G.; Amarakoon, R. Reliability and reproducibility of ceramic sensors. III: Humidity sensors. Am. Ceram. Soc. Bull. 1993, 72, 119-130.

66. Pianaro, S.; Bueno, P.; Longo, E.; Varela, J.A. A new $\mathrm{SnO}_{2}$-based varistor system. J. Mater. Sci. Lett. 1995, 14, 692-694.

67. Sekizawa, K.; Widjaja, H.; Maeda, S.; Ozawa, Y.; Eguchi, K. Low temperature oxidation of methane over Pd catalyst supported on metal oxides. Catal. Today 2000, 59, 69-74.

68. Amalric-Popescu, D.; Bozon-Verduraz, F., $\mathrm{SnO}_{2}$-supported palladium catalysts: activity in deNO $x$ at low temperature. Catal. Lett. 2000, 64, 125-128.

69. Du, W.; Yang, G.; Wong, E.; Deskins, N.A.; Frenkel, A.I.; Su, D.; Teng, X. Platinum-Tin Oxide Core-Shell Catalysts for Efficient Electro-Oxidation of Ethanol. J. Am. Chem. Soc. 2014, 136, 10862-10865.

70. Katayama, A. Electrooxidation of methanol on a platinum-tin oxide catalyst. J. Phys. Chem. 1980, 84, 376-381.

71. Dou, M.; Hou, M.; Wang, F.; Liang, D.; Zhao, Q.; Shao, Z.; Yi, B. Sb-Doped $\mathrm{SnO}_{2} \mathrm{Supported}$ Platinum Catalyst with High Stability for Proton Exchange Membrane Fuel Cells. J. Electrochem. Soc. 2014, 161, F1231-F1236.

72. Kakinuma, K.; Chino, Y.; Senoo, Y.; Uchida, M.; Kamino, T.; Uchida, H.; Deki, S.; Watanabe, M. Characterization of Pt catalysts on $\mathrm{Nb}$-doped and $\mathrm{Sb}$-doped $\mathrm{SnO}_{2-\delta}$ support materials with aggregated structure by rotating disk electrode and fuel cell measurements. Electrochim. Acta 2013, 110, 316-324.

73. Senoo, Y.; Kakinuma, K.; Uchida, M.; Uchida, H.; Deki, S.; Watanabe, M. Improvements in electrical and electrochemical properties of $\mathrm{Nb}$-doped $\mathrm{SnO}_{2-\delta}$ supports for fuel cell cathodes due to aggregation and Pt loading. RSC Adv. 2014, 4, 32180-32188. 
74. Yin, M.; Xu, J.; Li, Q.; Jensen, J.O.; Huang, Y.; Cleemann, L.N.; Bjerrum, N.J.; Xing, W. Highly active and stable Pt electrocatalysts promoted by antimony-doped $\mathrm{SnO}_{2}$ supports for oxygen reduction reactions. Appl. Catal. B 2014, 144, 112-120.

75. Kakinuma, K.; Uchida, M.; Kamino, T.; Uchida, H.; Watanabe, M. Synthesis and electrochemical characterization of $\mathrm{Pt}$ catalyst supported on $\mathrm{Sn}_{0.96} \mathrm{Sb}_{0.04} \mathrm{O}_{2-\delta}$ with a network structure. Electrochim. Acta 2011, 56, 2881-2887.

76. Savych, J.; Subianto, S.; Nabil, Y.; Cavaliere, S.; Jones, D.; Rozière, J. Negligible degradation on in situ voltage cycling of a PEMFC with electrospun niobium-doped tin oxide supported $\mathrm{Pt}$ cathode. Phys. Chem. Chem. Phys. 2015, 17, 16970-16976.

77. Chino, Y.; Taniguchi, K.; Senoo, Y.; Kakinuma, K.; Hara, M.; Watanabe, M.; Uchida, M. Effect of Added Graphitized CB on Both Performance and Durability of $\mathrm{Pt} / \mathrm{Nb}-\mathrm{SnO}_{2}$ Cathodes for PEFCs. J. Electrochem. Soc. 2015, 162, F736-F743.

78. Senoo, Y.; Taniguchi, K.; Kakinuma, K.; Uchida, M.; Uchida, H.; Deki, S.; Watanabe, M. Cathodic performance and high potential durability of $\mathrm{Ta}_{-} \mathrm{SnO}_{2-\delta}$-supported Pt catalysts for PEFC cathodes. Electrochem. Commun. 2015, 51, 37-40.

79. Saha, M.S.; Li, R.; Cai, M.; Sun, X. High electrocatalytic activity of platinum nanoparticles on $\mathrm{SnO}_{2}$ nanowire-based electrodes. Electrochem. Solid State Lett. 2007, 10, B130-B133.

80. Zhang, P.; Huang, S.-Y.; Popov, B.N. Mesoporous Tin Oxide as an Oxidation-Resistant Catalyst Support for Proton Exchange Membrane Fuel Cells. J. Electrochem. Soc. 2010, 157, B1163-B1172.

81. Wang, X.; Yang, Z.; Zhang, Y.; Jing, L.; Zhao, Y.; Yan, Y.; Sun, K. MnO2 Supported Pt Nanoparticels with High Electrocatalytic Activity for Oxygen Reduction Reaction. Fuel Cells 2014, 14, 35-41.

82. Dong, H.-Q.; Chen, Y.-Y.; Han, M.; Li, S.-L.; Zhang, J.; Li, J.-S.; Lan, Y.-Q.; Dai, Z.-H.; Bao, J.-C. Synergistic effect of mesoporous $\mathrm{Mn}_{2} \mathrm{O}_{3}$-supported $\mathrm{Pd}$ nanoparticle catalysts for electrocatalytic oxygen reduction reaction with enhanced performance in alkaline medium. J. Mater. Chem. A 2014, 2, 1272-1276.

83. Seger, B.; Kongkanand, A.; Vinodgopal, K.; Kamat, P.V. Platinum dispersed on silica nanoparticle as electrocatalyst for PEM fuel cell. J. Electroanal. Chem. 2008, 621, 198-204.

84. Sasaki, K.; Zhang, L.; Adzic, R.R. Niobium oxide-supported platinum ultra-low amount electrocatalysts for oxygen reduction. Phys. Chem. Chem. Phys. 2008, 10, 159-167.

85. Zhong, H.X.; Zhang, H.M.; Liu, G.; Liang, Y.M.; Hu, J.W.; Yi, B.L. A novel non-noble electrocatalyst for PEM fuel cell based on molybdenum nitride. Electrochem. Commun. 2006, 8 , 707-712.

86. Huang, T.; Mao, S.; Zhou, G.; Wen, Z.; Huang, X.; Ci, S.; Chen, J. Hydrothermal synthesis of vanadium nitride and modulation of its catalytic performance for oxygen reduction reaction. Nanoscale 2014, 6, 9608-9613.

87. Oyama, S.T. Introduction to the chemistry of transition metal carbides and nitrides. In The Chemistry of Transition Metal Carbides and Nitrides, Oyama, S.T., Ed.; Springers: Heidelberg, Germany, 1996; pp. 1-27.

88. Giner, J.; Swette, L. Oxygen Reduction on Titanium Nitride in Alkaline Electrolyte. Nature 1966, $211,1291-1292$. 
89. Avasarala, B.; Haldar, P. On the stability of TiN-based electrocatalysts for fuel cell applications. Int. J. Hydrogen Energy 2011, 36, 3965-3974.

90. Seifitokaldani, A.; Savadogo, O. Electrochemically Stable Titanium Oxy-Nitride Support for Platinum Electro-Catalyst for PEM Fuel Cell Applications. Electrochim. Acta 2015, 167, 237-245.

91. Wang, W.; Savadogo, O.; Ma, Z.-F. The oxygen reduction reaction on $\mathrm{Pt} / \mathrm{TiO}_{\mathrm{x}} \mathrm{N}_{\mathrm{y}}$-based electrocatalyst for PEM fuel cell applications. J. Appl. Electrochem. 2012, 42, 857-866.

92. Pan, Z.; Xiao, Y.; Fu, Z.; Zhan, G.; Wu, S.; Xiao, C.; Hu, G.; Wei, Z. Hollow and porous titanium nitride nanotubes as high-performance catalyst supports for oxygen reduction reaction. J. Mater. Chem. A 2014, 2, 13966-13975.

93. Zhang, R.-Q.; Lee, T.-H.; Yu, B.-D.; Stampfl, C.; Soon, A. The role of titanium nitride supports for single-atom platinum-based catalysts in fuel cell technology. Phys. Chem. Chem. Phys. 2012, 14, 16552-16557.

94. Avasarala, B.; Haldar, P. Durability and degradation mechanism of titanium nitride based electrocatalysts for PEM (proton exchange membrane) fuel cell applications. Energy 2013, 57, 545-553.

95. Yang, M.; Cui, Z.; DiSalvo, F.J. Mesoporous vanadium nitride as a high performance catalyst support for formic acid electrooxidation. Chem. Commun. 2012, 48, 10502-10504.

96. Zhou, X.; Chen, H.; Shu, D.; He, C.; Nan, J. Study on the electrochemical behavior of vanadium nitride as a promising supercapacitor material. J. Phys. Chem. Solids 2009, 70, 495-500.

97. Cao, B.; Neuefeind, J.C.; Adzic, R.R.; Khalifah, P.G. Molybdenum Nitrides as Oxygen Reduction Reaction Catalysts: Structural and Electrochemical Studies. Inorg. Chem. 2015, 54, 2128-2136.

98. Di Noto, V.; Negro, E. Development of nano-electrocatalysts based on carbon nitride supports for the ORR processes in PEM fuel cells. Electrochim. Acta 2010, 55, 7564-7574.

99. Di Noto, V.; Negro, E.; Giffin, G.A. (Keynote Lecture) Multi-Metal Nano-Electrocatalysts Based on Carbon Nitride Supports for the ORR and FOR in PEM Fuel Cells. ECS Trans. 2012, 40, 3-10.

100. Xu, L.; Li, H.; Xia, J.; Wang, L.; Xu, H.; Ji, H.; Li, H.; Sun, K. Graphitic carbon nitride nanosheet supported high loading silver nanoparticle catalysts for the oxygen reduction reaction. Mater. Lett. 2014, 128, 349-353.

101. Yan, Z.; Zhang, M.; Xie, J.; Zhu, J.; Shen, P.K. A bimetallic carbide $\mathrm{Fe}_{2} \mathrm{MoC}$ promoted Pd electrocatalyst with performance superior to $\mathrm{Pt} / \mathrm{C}$ towards the oxygen reduction reaction in acidic media. Appl. Catal. B 2015, 165, 636-641.

102. Li, Z.; Ji, S.; Pollet, B.G.; Shen, P.K. A $\mathrm{Co}_{3} \mathrm{~W}_{3} \mathrm{C}$ promoted Pd catalyst exhibiting competitive performance over $\mathrm{Pt} / \mathrm{C}$ catalysts towards the oxygen reduction reaction. Chem. Commun. 2014, 50, 566-568.

103. Ma, X.; Meng, H.; Cai, M.; Shen, P.K. Bimetallic Carbide Nanocomposite Enhanced Pt Catalyst with High Activity and Stability for the Oxygen Reduction Reaction. J. Am. Chem. Soc. 2012, 134, 1954-1957.

104. Chhina, H.; Campbell, S.; Kesler, O. Thermal and electrochemical stability of tungsten carbide catalyst supports. J. Power Sources 2007, 164, 431-440. 
105. Liang, C.; Ding, L.; Li, C.; Pang, M.; Su, D.; Li, W.; Wang, Y. Nanostructured $\mathrm{WC}_{x} / \mathrm{CNT}_{\mathrm{N}}$ as highly efficient support of electrocatalysts with low Pt loading for oxygen reduction reaction. Energy Environ. Sci. 2010, 3, 1121-1127.

106. Garcia, A.C.; Ticianelli, E.A. Investigation of the oxygen reduction reaction on Pt-WC/C electrocatalysts in alkaline media. Electrochim. Acta 2013, 106, 453-459.

107. Farsi, H.; Barzgari, Z. Chemical Synthesis of Nanostructured $\mathrm{SrWO}_{4}$ for Electrochemical Energy Storage and Conversion Applications. Int. J. Nanosci. 2014, 13, 1450013: 1-1450013:9.

108. Farsi, H.; Barzgari, Z. Synthesis, characterization and electrochemical studies of nanostructured $\mathrm{CaWO}_{4}$ as platinum support for oxygen reduction reaction. Mater. Res. Bull. 2014, 59, 261-266.

109. Kukino, T.; Kikuchi, R.; Takeguchi, T.; Matsui, T.; Eguchi, K. Proton conductivity and stability of $\mathrm{Cs}_{2} \mathrm{HPW}_{12} \mathrm{O}_{40}$ electrolyte at intermediate temperatures. Solid State Ionics 2005, 176, 1845-1848.

110. Dsoke, S.; Kolary-Zurowska, A.; Zurowski, A.; Mignini, P.; Kulesza, P.J.; Marassi, R. Rotating disk electrode study of $\mathrm{Cs}_{2.5} \mathrm{H}_{0.5} \mathrm{PW}_{12} \mathrm{O}_{40}$ as mesoporous support for Pt nanoparticles for PEM fuel cells electrodes. J. Power Sources 2011, 196, 10591-10600.

111. Yu, H.Y.; Feng, X.D.; Grozea, D.; Lu, Z.H.; Sodhi, R.N. S.; Hor, A.-M.; Aziz, H. Surface electronic structure of plasma-treated indium tin oxides. Appl. Phys. Lett. 2001, 78, 2595-2597.

112. Chhina, H.; Campbell, S.; Kesler, O. An oxidation-resistant indium tin oxide catalyst support for proton exchange membrane fuel cells. J. Power Sources 2006, 161, 893-900.

113. Liu, Y.; Mustain, W.E. High Stability, High Activity Pt/ITO Oxygen Reduction Electrocatalysts. J. Am. Chem. Soc. 2013, 135, 530-533.

114. Munro, R.G. Material properties of titanium diboride. J. Res. Nat. Inst. Stand. Technol. 2000, 105, 709-720.

115. Yin, S.; Mu, S.; Lv, H.; Cheng, N.; Pan, M.; Fu, Z. A highly stable catalyst for PEM fuel cell based on durable titanium diboride support and polymer stabilization. Appl. Catal. B 2010, 93, 233-240.

116. Yin, S.; Mu, S.; Pan, M.; Fu, Z. A highly stable TiB2-supported Pt catalyst for polymer electrolyte membrane fuel cells. J. Power Sources 2011, 196, 7931-7936.

117. Huang, Z.; Lin, R.; Fan, R.; Fan, Q.; Ma, J. Effect of $\mathrm{TiB}_{2}$ Pretreatment on Pt/TiB 2 Catalyst Performance. Electrochim. Acta 2014, 139, 48-53.

118. Roth, C.; Bleith, P.; Schwöbel, C.A.; Kaserer, S.; Eichler, J. Importance of Fuel Cell Tests for Stability Assessment-Suitability of Titanium Diboride as an Alternative Support Material. Energies 2014, 7, 3642-3652.

119. Bača, L.; Stelzer, N. Adapting of sol-gel process for preparation of $\mathrm{TiB}_{2}$ powder from low-cost precursors. J. Eur. Ceram. Soc. 2008, 28, 907-911.

(C) 2015 by the authors; licensee MDPI, Basel, Switzerland. This article is an open access article distributed under the terms and conditions of the Creative Commons Attribution license (http://creativecommons.org/licenses/by/4.0/). 